\title{
Postwar Pines: The Military and the Expansion of State Forests in Post-Imjin Korea, 1598-1684
}

\section{JOHN S. LEE}

This article explains why the Chosŏn government and the military in particular expanded state control over forests in the seventeenth century and analyzes the implications of forest administration in a preindustrial polity. From 1592 to 1598, the Chosŏn dynasty suffered invasions from Japan that displaced much of the Korean population and devastated the economy and environment. The crucial role of the navy during the war, along with a dire postwar situation, heightened government anxieties about deforestation and timber scarcity. Thus, in the seventeenth century, the Chosŏn government expanded administration over forests, particularly pine forests, across the coasts and islands of southwestern Korea. The key vehicle for the expansion was the military. Due to wartime and postwar exigencies, the military became the late Chosŏn state's primary organ for management of wood resources for state purposes. Furthermore, the growth of pine-centric state forests and shifts in military priorities would significantly reshape Korean ecologies.

Keywords: Chosŏn Korea, early modern state, environmental history, forestry, Imjin War, Korean history, logging, military, pine, wood resources

F OR Korea, the Imjin War (1592-98) was an unmitigated tragedy. ${ }^{1}$ An estimated 20 percent of the population died or was abducted during the conflict. Arable land was reduced to 66 percent of the prewar total. Countless buildings were left in ashes, including all three royal palaces and three out of the four depositories of the official court annals, the Veritable Records of the Kings of the Choson Dynasty. Upon returning to the ruined capital, Hansŏng (present-day Seoul), King Sŏnjo (r. 1552-1608) had to take refuge in the home of a royal relative.

The overall impact of the conflict, however, has been subject to debate. Japanese historians during the colonial era marked the Imjin War's aftermath as part of Chosŏn Korea's long road to decline. Korea’s “internal development” school historians profoundly disagreed: they saw the postwar context not as stagnation but as stimulant for reforms and economic expansion. Some historians have downplayed the concept of the Imjin War as watershed, observing that the transition between the sixteenth and seventeenth centuries was remarkable for its sociopolitical continuity (Deuchler 2015; Kim Sŏngu 2001). Most recently, JaHyun Kim-Haboush (2016) has argued that the Imjin War, what she calls “The

John S. Lee (john.s.lee@yale.edu) is Postdoctoral Associate in Agrarian Studies at Yale University.

${ }^{1}$ Toyotomi Hideyoshi's (1536-98) two invasions of Korea are also referred to in this article as the "Hideyoshi invasions." In order to succinctly reference the continuum and context of the wartime era, the primary usage will be the "Imjin War." 
Great East Asian War," was critical to the shaping of Korean national identity from the late Chosŏn era to the twentieth century.

When it comes to Korea's environmental history, the impact of the Hideyoshi invasions cannot be dismissed. Whether in building the famed fleets of Admiral Yi Sunsin (1545-98) or falling victim to arson and ground combat, forests suffered. Uprooted people became shifting cultivators and vagrants, bringing to the Chosŏn court alarming tales of burned forests, eroded hillsides, and flooded fields. Finally, the postwar Chosŏn government found itself needing forests to rebuild government buildings and the navy.

In this article, I explain why the central government expanded state forestry in the seventeenth century, an era I call "post-Imjin Korea," and analyze how the military became a key vehicle for widening state control over sylvan environments. I concentrate on the effects of the war and postwar recovery on the pine forests of western and southern Korea, in the provinces of Ch'ungch'ŏng and Chŏlla. There, since the beginning of the dynasty, the Chosŏn government had established forests reserved for "state use" (kugyong). The same forests provided the raw material for crucial naval victories during the Imjin War. After the war, the government cordoned off more forests along the coasts and the islands that dot Korea's southwestern shores. Expanding upon wartime patterns, military garrisons managed the logging and replanting of forests and guarded against threats ranging from swidden cultivators and ordinary woodcutters to the tiny larvae of the pine moth (Dendrolimus spectabilis).

The expansion of state forestry in the early-to-mid seventeenth century was the government's response to the costs of war, namely the heavy logging of forests in the southwest for naval construction, combined with a dire postwar situation that drove fears of deforestation and timber shortage among policymakers in the Chosŏn court. In the context of early modern Eurasia, Korea was not alone in facing the linkage of war, bureaucratic expansion, and forests. Paul Warde (2006) has argued that the specter of timber scarcity stalked numerous European states between 1450 and 1850. Recent studies have shown how, from Japan to Italy, France, and Spain, the rise of the early modern state was tied to mounting demands for timber coupled with the expansion of government capacity to manage forest use (Appuhn 2009; Matteson 2015; Totman 1998; Wing 2015). Likewise, in Korea after the Imjin War, the Chosŏn government expanded control over southern and western coastal forests, in particular pine forests. Key to the process was the military, which took on a key role in implementing forest policy on the ground, guarding the forests, finding suitable timber, and even providing labor. But why? The late Chosŏn military was not a prestigious branch of the Chosŏn bureaucracy. Nor were military officials considered particularly honest or virtuous.

Changes in government priorities and in the land made the match between the military and the forest. Wartime practices, particularly the wide use of soldiers for forestry work, expanded into the postwar era. As government and military priorities shifted toward rebuilding finances and the navy, state ranches (mokchang) along the coasts and islands that had once supplied cavalry and packhorses were converted to taxable fields and state forests. The military also expanded the functions of preexisting institutions such as the naval garrison (sugunjin) to further support the growth of state forestry in the mid-to-late seventeenth century.

The post-Imjin expansion of state forestry demonstrates how a preindustrial polity could dramatically transform landscapes through the mere flexing of policy. The 
Chosŏn state’s privileged landscape, the pine forest, became a key cog in the government's efforts to rehabilitate state authority and the countryside after the Imjin War. Historically, two types of pines have provided high-quality timber on the Korean peninsula: Pinus densiflora and Pinus thunbergii. Both species reach maturity quickly, in twenty to thirty years, and prosper across Korea's humid continental climate into the mountainous interior and particularly along the ria coastlines and islands in the southwestern reaches of the peninsula. ${ }^{2}$ Their timber was straight, sturdy, and easy to work and float, with wide applications from edifice construction to coffins and ships.

Moreover, pines had significant cultural and workaday value. Pines were symbols of longevity, loyalty, virtue, and even masculinity. Pines are the most common tree in Chosŏn poetry (Chŏn 2005, 157). Their high burning temperature made them useful for manufacturing everything from pots and weapons to salt and for simply heating the home. Pine resin was the basis for common adhesives; in desperate times, pine needles and bark were considered good famine food. From high to low, across multiple spheres of Chosŏn life, pines were a valued, critical resource. State forestry was the government's method of privileging its access to a contested materiality.

The Chosŏn government expedited the dominance of pine through so-called "pine protection policies" (songjŏng, kümsong) and by labeling most other trees, outside of those for silvicultural use, as "miscellaneous trees" (chammok) open to logging. Pinus densiflora and Pinus thunbergii are shade-intolerant species that prosper after deciduous competitors have been reduced. Accordingly, government policy, with the military as the primary implement, helped pines flourish along the western and southern coasts during the seventeenth century. The conversion of former state ranches along the coasts and islands to protected "Pine Fields" (songjŏn) further benefited pine forest environments, though to the detriment of Korean cavalry stocks.

My argument tightens the link between wartime practices, postwar exigencies, and environmental change. Naval victories may have saved the Chosŏn state, but they also fostered new worries over deforestation. Postwar concerns thus produced an expanded state forest system centered on protecting the pine forests of western and southern Korea. The continuation of wartime practices allowed military institutions to take a central role in crafting the postwar pine-dominant landscape. Accordingly, since my argument concerns the relationship between government and the environment, my main source material is derived from the Chosŏn state's central records, particularly policyrelated sources from the Veritable Records of the Kings of the Chosŏn Dynasty (Chosŏn Wangjo Sillok) and the Records of the Border Defense Command (Pibyŏnsa Tüngrok). Diaries, literati records (munjip), treatises, and gazetteers add further insight into the nexus of environmental and institutional change in post-Imjin Korea.

\section{The Environmental Legacies of Victory, 1592-98}

Yi Sunsin, perhaps Korea’s most renowned military hero, became famous for defeating much larger Japanese fleets along Korea's southern coasts. The basis of his naval

${ }^{2}$ As of 2006, 42.2 percent of the Republic of Korea's forests were coniferous, 26 percent were deciduous, and 29.3 percent were mixed (Kim Kyoung-soo 2010, 8). 
victories, along with his tactical acumen and heavy Ming Chinese assistance, was a concentrated fleet of warships based in the island and coastal regions of southwestern Korea. The mainstay of the fleet was the double-decked warship (Panoksŏn) first introduced in 1555, supported by the more famous Turtle Boat (Kŏbuksŏn, Kusŏn). The source of the warships was the coniferous forests that stretch across the coastlines and islands of western and southern Korea, with Pinus densiflora and Pinus thunbergii providing the bulk of the high-quality timber.

However, pine had not always been the dominant tree species on the peninsula. Historical surveys of construction material conducted by Pak Wŏn'gyu and Yi Kwanghŭi (2007) indicate that oak was the prevailing material during ancient times and the Three Kingdoms era (57 BCE - $668 \mathrm{CE}$ ), respectively constituting 94 percent and 57 percent of surveyed sites. In contrast, pine composed 6 percent of surveyed Three Kingdoms-era edifices. Then suddenly in the Koryŏ dynasty (918-1392), pine took on 71 percent of surveyed construction material, a dominance that only intensified in the early-to-mid Chosŏn (73 percent) and late Chosŏn (88 percent) eras.

The "pine explosion" of the Koryo era likely sprang from a combination of causes. The era coincides with the Medieval Warm Period of 950 to 1250, though it is still uncertain how exactly warmer or rainier climates affected Korean flora. Cultural predilections had an undeniable effect. Protection of trees, particularly pines, was central to early Koryŏ geomantic beliefs that tied terrestrial management to political legitimacy and cosmic order. For instance, the foundation legend of the Koryŏ ruling house includes an ancestor named Kangch'ung who planted pines on the hills above the eventual capital, Kaesŏng, in order to fulfill a prophecy that "whoever planted pines on the rocky slopes" would produce the unifier of the Korean peninsula (Koryŏsa Segye 2001, 1:6-11; Rogers 1982-83, 6-7). Fittingly, Kaesŏng was alternatively called "Songak," meaning "Pine Hill."

Furthermore, the era of Mongol Yuan domination of the Korean peninsula (12711368) forged an initial link between war, the state, and pine environments. In preparation for their failed invasions of Japan, Mongol generals ordered significant amounts of timber to be extracted from the southern and western coasts of Korea (Henthorn 1963, 207-8, 223). Nautical archaeological studies of sunken Yuan warships lend evidence to the notion that the primary construction material for Korean vessels in the thirteenth century was indeed pine (Sasaki 2015, 37-40, 118-19, 142-46). By the mid-fourteenth century, as the Mongols retreated from the Korean peninsula, Koryŏ elites in Kaesŏng were privileging the ubiquitous, easily workable pine over all other trees. The poem "Woodcutting Youth" (Ch'odong) by late Koryŏ scholar-official Yi Saek (1328-96) narrates the labor of a young woodcutter logging copious pine stands around the Koryŏ capital amidst "not a single miscellaneous tree" (Yi Saek, n.d.).

In the early fifteenth century, the new Chosŏn dynasty cordoned off hundreds of pine forests as "Restricted Forests" (kümsan) for state use. ${ }^{3}$ Pine timber from these state forests was reserved for warship, edifice, and coffin construction. The government found the labor to fell and transport trees by applying corvée levies to villages in the vicinity of Restricted Forests. Over the course of the late fifteenth and sixteenth centuries, the

${ }^{3}$ For a list of Restricted Forest locations, see Sejong Sillok (n.d., 1448/8/27). 
Restricted Forest system became prone to lax enforcement as the expansion of arable land and local priorities took precedence over forest protection. For instance, in the Haenam region of Chŏlla that would later serve as Yi Sunsin's base, a local elite named Yu Hŭich'un (1513-77) regularly colluded with forest officials to acquire construction timber for tasks as mundane as building houses for his concubine (Yu 1992-96, 1567/ $12 / 17,1569 / 2 / 11)$.

Once the Imjin War began however, the government made a concerted effort to clamp down on corruption, allowing the Restricted Forests and accordant corvée institutions to provide the crucial raw material for Chosŏn's early naval victories. In the first years of the war, Yi Sunsin fulfilled his lumbering and shipbuilding needs by corvéeing skilled woodworkers, carpenters, and lumberjacks, collectively referred to as mokchang and yŏkkun. In the summer of 1593, over 241 local men were called up to fell trees and build ships (Yi Sunsin 2010, 1593/6/19). When one village did not send the requisite number of carpenters and lumberjacks, Yi punished the naval officers and local petty officials (ajŏn) in charge of levy collection for "untrustworthy and deceitful acts" (1593/6/22).

As the war progressed, military conscription provided extra boosts of logging manpower. When another wave of shipbuilding began in 1596, Yi had 1,090 men from three different provinces, rather than just local corvée levies, to haul down timber (Yi Sunsin 2010, 1597/10/29, 1597/10/30). The shift from local levy to military labor was significant. After the Imjin War, a similar system, led by naval officers and labored by soldiers, would be applied to state forests across the western and southern coasts. There, the postwar landscape would be one of naval garrisons and protected pine forests.

For almost the entirety of the war, Korea's most significant fighting force, its navy, was based in the southwest and island zones. Significant stretches of Ch'unchŏng and Chŏlla forests were cleared for the admiral's fleets and for new naval bases. Moreover, environmental changes to the islands and coasts of southwestern Korea were not limited to tree felling. Yi and his men spent much of their time hunting down game, particularly deer, boars, and leopards, in the surrounding vicinity. As with all preindustrial armies, germs were just as dangerous as the enemy. Disease decimated up to 10 percent of the 6,000 sailors under Yi's command in 1593 and 1594 (Yi Min'ung 2015). Food shortages exacerbated the illnesses. In response, Yi maintained and expanded garrison farms (tunjŏn) to supply necessary provisions. On these farms, tenants paid their rent directly to the military. While Korean officials had intermittently adopted garrison farms during the Koryo and early Chosŏn, their usage and placement would intensify during and after the Imjin War. ${ }^{4}$

Hideyoshi's land invasion had further environmental costs. Millions of Koreans were displaced and killed as Hideyoshi's troops marched through the peninsula. Fire accompanied the armies as weapon and byproduct. Forests were cleared to make camps, ramp up fortresses, and manufacture weapons and ships. While on a mission in 1596, Yi Sunsin lamented the "desolation in the country houses and farms," and he resolved to one day relieve the locals of the "arduous task" of maintaining warships (Yi Sunsin 2010, 1596/8a/14). Chief State Councilor Ryu Sŏngryong (1542-1607), who had

${ }^{4}$ For a definitive study of Chosŏn garrison farms, see Song Yangsŏp (2006). For an analysis of the logistical and environmental situation in northern Korea during the Imjin War, see Hasegawa (2016). 
commanded overall military operations during the latter stages of the war, likewise noted the immense postwar desolation. "The mountains and valleys lack trees," Ryu wrote, "and so no one can block the landslides." He observed that "the forests were bare" and that "tigers and leopards wandered far" amidst the habitat loss, and warned, ominously, that "trees for timber were wasting away" (Chŏng Yakchŏn [1804] 2002, 221).

\section{Reclaiming Forests for the State, 1598-1623}

In the ensuing postwar recovery, a particular concern for the government was the specter of timber scarcity. High-quality timber was still essential for warships and edifices. Hideyoshi's troops had burned countless buildings across the peninsula, including the main royal palaces and government structures. The court also feared the return of another invasion force from the archipelago. Meanwhile, in the devastated countryside, ordinary Koreans needed to reclaim land and rebuild their homes, actions that in turn required forest resources. In the post-Imjin era, forests became an increasingly contested materiality that drew in more government intervention.

The government's first move was to check the condition of the forests. In 1606, the court dispatched a series of "logging assessors" (pŏlmok kyŏngch'agwan, pŏlmok ŏsa) across the country to inspect Restricted Forests (Sŏnjo Sillok, n.d., 1606/7/22). Logging assessors usually came from the higher ranks, and they included senior officials such as Yu Kyŏngjong (1565-1623) and Kim Kwangp'il (1553-1608). The court typically sent out the logging assessors in the autumn, after the summer rains and before the winter timber harvest. Once they reached their destinations, the assessors would inspect the local forests and inquire with local officials and the populace about forest-related conditions.

A subsequent report from 1610 noted the continuation of "indiscriminate pine logging" near the coastal point of Changsan in Hwanghae Province and in Pyŏnsan in Chŏlla Province, where "Restricted Forests had been cultivated since the founding of the dynasty." In response, King Kwanghaegun (r. 1608-23) reiterated that logging was to be "generally banned" in the Restricted Forests, and "the duty to protect and nourish" the forests was to be "relayed to the officials across the eight provinces." The postwar environment had provoked the king's anxieties. "After the recent calamities," declared Kwanghaegun, "any unregulated logging is highly destabilizing” (Kwanghaegun Ilgi, n.d., 1610/2/12).

Over the course of the 1610s and 1620s, logging assessors continued to uncover unregulated felling in the pine-rich areas of coastal Ch’ungch'ŏng and Chŏlla, precisely the same areas that had built Yi Sunsin's mighty fleets (Kwanghaegun Ilgi, n.d., 1614/ 7/18, 1615/1/9). A noteworthy area of concern was Pyŏnsan, a small promontory in Chŏlla Province that juts into the Yellow Sea. Pyŏnsan had long been famous for its highquality pines. The Mongols had harvested timber there in the 1270s, and the early Chosŏn government established a Restricted Forest in the same area. During the Imjin War, the Pyŏnsan pine forests proved critical as a naval supply zone. Two decades after the war's conclusion, however, a logging assessor reported to the court that the Restricted Forests of Pyŏnsan were "lacking tall timber." He placed the blame on local officials for "felling and taking trees as they pleased" while turning a blind eye to fellow transgressors (Kwanghaegun Ilgi, n.d., 1620/10/21). 
In response, Kwanghaegun assigned more forest wardens (sanjik) to the area and ordered military officials to crack down on any negligence and corruption. State forest warden positions were usually lower-level administrative posts granted to soldiers or local residents. Though the position was not high in status, wardens were granted exemptions from all other types of corvée labor. Military officials and wardens were given the additional duty of grading Pyŏnsan's trees as "large, middle, or small" and recording their quantity. The new controls placed on Pyŏnsan had eventual success. Half a century later, in 1678, a government report recommended that pine seedlings from Pyŏnsan be used to replant pines in other, more struggling state forests (Sukchong Sillok, n.d., 1678/10/23). Another 1728 report records the requisition of 5,281 "small, middle, and large" pines from the same area, a huge number indicative of a managed, regenerating forest (Pibyŏnsa Tüngrok 1949, Yŏngjo, 1729/4/19).

The postwar logging assessors not only found evidence of unregulated logging but also awakened the court to possible flaws within the state forestry system. In 1607, Kim Kwangp'il notified the court that the reconstruction of Seoul's palaces was taking a toll on the populace of Kangwŏn Province. When requisition orders came in, residents near state forests had to cease farming in order to assist with logging and transportation. For an unskilled corvée laborer, logging was as dangerous as it was arduous. In one case, a hundred laborers were needed to fell a mere few trees and then haul them onto the Han River, with several men drowning and dying in the process (Sŏnjo Sillok, n.d., 1607/4/4).

Kim Kwangpil's observations reflected a general problem of labor recruitment that would spur more state forestry reforms during the seventeenth century. In 1616, the Seoul Magistracy (Hansŏngbu) tried to corvée Seoul residents to plant more pine trees in the mountains and hills around the capital, primarily by transplanting saplings. Yet, "seven to eight out of every ten" households chose to disobey the order. The workers' resentment toward reforestation work can be seen in a ditty from the period:

South Mountain pines make North Mountain pines,

North Mountain pines make South Mountain pines.

Daily we move and plant pines without end

And live pines make dead pines. (Kwanghaegun Ilgi, n.d., 1616/2/15)

To tackle the problem, Kwanghaegun ordered the military to appoint more wardens as lower-level administrative officials to oversee planting and forest patrols. Increasingly over the course of the seventeenth century, Chosŏn officials would establish a more precise state forestry hierarchy composed of military officials as state forest managers; wardens as day-to-day supervisors; and, following the pattern set by Yi Sunsin during the Imjin War, rotating-duty soldiers as the forest labor.

In 1623, government officials overthrew Kwanghaegun and installed his nephew Injo (r. 1623-49) on the throne. Yet, amidst all the political turmoil, there was no opposition to the expansion of state forestry. Deposing the monarch would not halt the strengthening of state forests along the western and southern coasts. What is more, Injo and his successors would use the military to extend state forests into a new frontier: islands. 


\section{IsLANDS into GarRisons, Ranches INTO ForESTS, 1598-1684}

Over three thousand islands dot the waters around the Korean peninsula, with the great majority of them lying off the western and southern coasts. Historically, the island zone has played a crucial role in the interplay between states and resources on the peninsula. During the seven brutal years of the Hideyoshi invasions, however, refugees of all backgrounds sought safety in the same areas. More fled toward the coasts and islands during the Manchu invasions of 1627 and $1636 .^{5}$ The influx of people gradually overwhelmed the old state ranches. In 1635, an official from the Royal Stables Administration (Saboksi) complained that only 46 out of the 119 state ranches were actually raising horses. Most had become overrun with residents reclaiming them into paddy land. Numerous ranches located on the mainland coast also underwent similar conversion. Near the Chŏlla hamlet of Hŭngyang, ten out of sixteen ranches were listed as “defunct" (p’yejang) (Hŏ 1663; Kim Kyŏngok 2004, 117).

While fifteenth- and sixteenth-century Chosŏn armies had fielded large divisions of cavalry, the military's equine element declined after the Imjin War. General Sin Ip's (1542-92) vaunted cavalry units, painstakingly built and trained to fight Jurchen raiders, were destroyed in the first year of the Imjin War at the Battle of Ch'ungju. Combined with Sin Ip's fatally inept decision-making, the Korean cavalry was no match for Hideyoshi's arquebuses (Swope 2005, 39-40). After the war, the Chosŏn government placed increasing emphasis on warships and gunpowder weapons at the expense of horses. ${ }^{6}$ Chinese demands for horses as part of the international tribute trade also diminished. Moreover, arable land could replenish state finances far more quickly and effectively. As a Chosŏn official put it in 1680: "In a year, one reclaimed field can recoup the value of several horses. Why not move the horses and let people come into the islands to farm?" (Sukchong Sillok, n.d., 1680/2/3).

Amidst the declining ranches, another key resource flourished. Ever since the dynasty's early years, state ranches had heavily overlapped with the locations of Restricted Forests. ${ }^{7}$ Pinus densiflora and Pinus thunbergii, as light-demanding species generally unmolested by livestock, grew well near the island ranches and prospered as the ranches went defunct. The domestic horse is a browser that prefers a mixed diet of grass, shrubs, flowering plants, and young trees. Horses enjoy feeding on young deciduous trees; however, they shun most conifers, including pine (Vera 2000, 26-28). The great white pine stands of New England, for instance, are a byproduct of the heavy grazing regime that proliferated in eastern North America during the early nineteenth century (Whitney 1994, 170). Decades of horse grazing led to the elimination of hardwoods and left more open seedbeds in which the shade-intolerant pine prospered.

\footnotetext{
${ }^{5}$ For a list of southern elites who fled to the islands during the Imjin conflict, see Kim Kyŏnggok (2004).

${ }^{6}$ For a discussion of the late Chosŏn transition of gunpowder weaponry, see Kang (2013) and Andrade, Kang, and Cooper (2014).

${ }^{7}$ For an example of the early Chosŏn establishment of ranches in Haenam, see Tanjong Sillok (n.d., 1454/6/4). For a map and list of late Chosŏn horse ranch locations, see Hŏ (1663) and Nam (1996, 231).
} 
In post-Imjin Korea, policy and ecology converged to expand state forests at the expense of ranches and horses. As the navy and gunpowder overrode cavalry in military affairs, abandoned ranches transitioned into protected pine forests or new farms in the island zones. In 1615, Kwanghaegun requested that officials strictly regulate felling of "large trees not just in Restricted Forests" but also "in the provinces and on each island where there are timber stands" (Kwanghaegun Ilgi, n.d., 1615/5/16). As the seventeenth century wore on, numerous military ranches in southern Chŏlla island and coastal areas were converted to either state forests or farmland. On Nohwa island, old horse ranches established by the Chosŏn government in the fifteenth century were replaced with Pine Fields in the 1650s (Pyŏn 2012, 106-9). In 1675, the government decreed that any further farming and ranching on Amt'ae island were to be prohibited, and the island's pines were to be reserved for naval use. Another order in 1682 announced the conversion of ranches on Anch'ang and Kijwa islands to taxable farms (Kim Kyŏngok 2004, 117). Once Chosŏn officials realized that they could not stem the tide of new migrants into the islands, they encouraged residents to reclaim pastureland into taxable fields that could be added to post-Imjin Korea's dilapidated coffers. Timber and taxes became higher priorities than the horse.

In 1470, an estimated 40,000 horses roamed the state ranches of the peninsula. By 1678 , that number had dropped by half to 20,213. Chŏlla Province experienced a decline from 4,523 horses in 1470 to only 2,465 horses remaining in 1678. Even Cheju island, long the horse pasture of Korea, experienced a 53 percent drop from 26,502 to 12,411 horses in the same time span (Nam 1996, 236-37). Quality of stock also declined over the course of the dynasty. By the early nineteenth century, the prolific scholar-official Chŏng Yagyong (1762-1836) was describing "so-called military horses" as "only as big as donkeys ... and as small as rats," their bodies "infected with rashes and boils" from neglect and poor breeding (Chŏng Yagyong 2000, 4:8:1).

In contrast, state forests and pines increased in number and significance. In 1448, 291 Restricted Forests spanned across the Korea's coastlines; by 1808, that number had expanded to 678 sites. The majority of the new forests were established in the Naktong River basin in Kyŏngsang Province and the island regions of southwestern Korea (Man'gi Yoram 1971, 1:498-500). As Chŏng Yagyong’s brother, Chŏng Yakchŏn (1758-1816) would note in 1804, "When palaces, houses, ships, carriages and coffins are constructed, we all rely on the pine.... The country is 60 to 70 percent upland, and moreover, the uplands are all suitable for pine" (Chŏng Yakchŏn [1804] 2002, 220).

In addition, more than two centuries after the Imjin War, the crucial roles of the navy and naval supplies remained ensconced in memory. "Our country," Chŏng wrote, "is pressed near Japan and so with Japan we inevitably have naval warfare. During the disturbances of the Imjin year, we solely relied on our navy." He warned against the dire consequences of forest mismanagement, exclaiming, "If there were [another] crisis, where would we acquire the timber for a hundred ships?” (221). As pine timber magnified into an object of national importance, military priorities in turn shifted, leaving significant imprints on the flora and fauna of southern and western Korea. 


\section{A Postwar Landscape}

The naval garrison (sugunjin) served as a center of operations for the expansion of state forestry in the coastal and island regions. The early Chosŏn state had established naval garrisons along the southern and western coasts to guard against the pirate threat that plagued Korean waters in the fifteenth and sixteenth centuries. The same garrisons provided the infrastructural basis for Yi Sunsin's success during the Imjin War. After the war, the garrisons took on a larger role in other areas of resource management, ranging from salt and fish tax collection to forestry. Reforms enacted in the midseventeenth century enabled naval garrisons to reduce ship crews and instead dedicate more troops to tax collection and labor (Song Kijung 2011). Naval garrisons were numerous; by 1808, Chŏlla Province alone had forty naval garrisons spread along its coasts and islands with a listed total quota of 32,918 troops (Man'gi Yoram 1971, 2:490-92).

The role of the naval garrisons became particularly significant in the island and coastal zones near state forests, where they were assigned a wide range of forest-related duties.

For instance, in 1674, the government ordered Karip'o naval garrison in coastal Cholla Province to guard naval-grade pine timber, construct and repair warships, and even find coffin-grade timber (hwangjang) for royal use. The garrison duly assigned fifty wardens to identify and guard coffin-grade forests (Honam Chinji 1895, 83-84; Kim Kyŏngok 2004, 193). The same year, nearby Hoeryŏngp'o garrison began planting pines in their assigned state forests until, according to a nineteenth-century gazetteer, "their lushness blanketed the mountains in greenery." The garrison commander also assigned one local resident to oversee periodic logging (Honam Chinji 1895, 2:46-47).

When the central government promulgated a vast new set of forestry regulations in 1684 and 1691, it gave garrison commanders vast authority-and responsibility-over state forests across western and southern Korea (Pibyŏnsa Tüngrok 1949, Sukchong $1684 / 2 / 30,1684 / 11 / 26,1691 / 5 / 3)$. In addition to the management of logging and transportation, coastal garrisons had to guard against threats old and new: illicit loggers, swidden cultivators, pine moth larvae, and even illegal tombs. By the late seventeenth century, people across Korea were burying their dead in "auspicious" areas and claiming the surrounding land, particularly valuable woodland, as family property. ${ }^{8}$ The 1684 regulations prohibited any interring of bodies within state forest boundaries. Violators would be forced to excavate and reinter the corpses outside the state forests, after which they would be further punished according to the "statutes against grave theft" (t'ujang). Strict new procedures demanded that wardens report any discrepancies such as burned or clear-cut forests, and the regulations also designated punishments for officials who took bribes and turned a blind eye to forest-use practices not in accordance with the government's timber-centric interests.

It is important to note that "successful" expansion of state forestry in the post-Imjin era, while conducive to political stability, certainly did not benefit the lives of the majority of Chosŏn-era Koreans. State forestry was as political a project as it was environmental, a regulative drive meant to impose the state's preferred practices over a selective ecology.

${ }^{8}$ For an analysis of late Chosŏn tomb proprietary issues, see Kim Kyŏngsuk (2012) and Kim and $\operatorname{Kim}(2014)$. 
Extensive bureaucratic procedures helped pine forests recover and prosper for statist needs, not general welfare. The spread of the naval garrisons into the island zones marked the further intrusion of Chosŏn government officials into the workaday uses of forests. The scholar-official Yun Sŏndo (1587-1671), a native of the south Chŏlla region, complained that new forest regulations hampered local lives. Coastal residents and islanders "did not even dare to peer into pine forests" out of fear of government regulations. Meanwhile, legally accessible "mixed forest" (chapsu) had become "but few" due to decades of population pressures (Yun 1655).

Yun Sŏndo described the new pine protection laws as "overly strict." "It is not just the wardens who patrol and investigate," Yun wrote. "The garrison commander as well pursues and investigates. If there is even a minor transgression, a navy officer comes and punishes them.... The residents fear pines like they are tigers." State intrusion did not necessarily nourish obedience. Yun observed that the people, fearing punishment, no longer reported illegal felling or fires. Yun castigated the state's policies, in terms common among late Chosŏn rural literati, for abandoning Confucian principles in favor of resource extraction. "What the state should love and cherish," he wrote, "is surely its people, not pines. But now, it is on behalf of pines and does not look after its people" (Yun 1655).

Yun's assessment was accurate: post-Imjin policies had enabled pines to flourish, with the military as their primary protector. Wartime experiences and continuing concerns over timber scarcity produced a postwar landscape of pines and naval garrisons across the coastlines and islands of western and southern Korea. As with any environmental shift, there were winners and losers. Trees lacking government protection, particularly oak and zelkova, were easy victims for the axe and plow. State forests and their pine grew over state ranches and their diminishing horses. The government's successful imposition of its preferred sylvan ecology required new administrative controls on local residents as well as the prosecution of any land-use practices deemed threatening to the state's pine forests. Accordingly, in subsequent centuries, forest usage would be a focal point of conflict, as foreshadowed in Yun Sŏndo's remarks, between administrators and local residents.

On a concluding note, let us return to a certain initiator of Chosŏn's post-Imjin era. Across the Tsushima Strait in the seventeenth century, Japan underwent a similar process of timber depletion, scarcity concerns, and subsequent development of forestry institutions. Conrad Totman has described the years between 1570 and 1670 as a century of "early modern predation" in Japanese forest history, an era when elites triggered massive construction projects from above and population booms converted woodland to farm and fuel from below. As in Korea, war was a primary catalyst for forest depletion on the archipelago. Warlords used forests to fuel their battles and left burned forests in their wake. Hideyoshi's wars required forest exploitation on a national level. Even after Hideyoshi's shipbuilding levies were finished, Tokugawa Ieyasu (1543-1616) and his daimyo solidified the new Edo regime with monumental construction projects (Totman 1998, 50-69).

Consequent timber scarcities compelled the Tokugawa government to protect forests across the archipelago for statist needs, mostly by establishing protection and regenerative forests and restricting usage by commoners. However, while the catalyst for forest controls and the pattern of top-down imposition were similar to those of 
Korea, the different institutional structure of the Tokugawa regime produced a more diffuse set of forestry institutions situated in the context of each local han. The bakufu mandated various forestry policies, but implementation required cooperation with local lords and village headmen. The more centralized Chosŏn government, meanwhile, privileged a single type of sylvan landscape, and the bureaucracy in turn could wield the military to shape ecology according to mandated pine policies, particularly in coastal and island regions where local interests could be overcome or ignored. Thus, the Imjin War would set both the peninsula and archipelago on paths toward more intensive state forestry, but contrasting roles for the military and the more determined imposition of pine landscapes in Korea would produce divergent forest institutions and environments in subsequent centuries.

\section{Acknowledgments}

This research was possible thanks to support from the Korea Foundation, the Korea Institute at Harvard University, and the Fulbright Program. I would also like to thank Sun Joo Kim for her essential comments on early and later versions of this manuscript; the participants of the "New Frontiers in Premodern Korean Studies" workshop at Harvard University for their vital comments and corrections; Brian Donahue and his forest history class at Brandeis University for providing key insights during the research process; and the two anonymous reviewers for their kind and thoughtful suggestions.

\section{List of References}

\section{Primary Sources}

Chŏng Yagyong. 2000. Mongmin Simsŏ [Essays from the Heart on Governing the People]. Translated into Korean and edited by Tansan Yon'guhoe. Seoul: Ch’angbi.

Chŏng Yakchŏn. [1804] 2002. “Songjŏng Saŭi” [A Personal Treatise on Pine Administration]. Munhŏn kwa Haesŏk 20:220-25.

Hŏ Мок. 1663. Mokchang Chido [Map of State Ranches]. National Library of Korea.

Honam Chinji [Guide to Honam Garrisons]. 1895. Vols. 1-3. Seoul: Kyujanggak Institute of Seoul National University.

Koryŏsa Segye [Genealogy of Koryŏ]. 2001. In Koryŏsa [History of Koryŏ]. Seoul: Sinsŏwŏn.

Kwanghaegun Ilgi [Daily Record of King Kwanghae-gun]. n.d. In Chosŏn Wangjo Sillok [Veritable Records of the Kings of the Chosŏn Dynasty]. 48 vols. Seoul: Kuksa P’yŏnch’an Wiwŏnhoe.

Man'Gi Yoram [Essentials of State Affairs]. 1971. Translated into Korean and edited by Koryŏ Taehakkyo Minjok Munhwa Yŏn'guso. Seoul: Minjok Munhwa Ch’ujinhoe.

Pibyŏnsa Tŭngrok [Record of the Border Defense Command]. 1949. 16 vols. Seoul: Kuksa P’yŏnch'an Wiwŏnhoe. 
Sejong Sillok [Veritable Records of King Sejong]. n.d. In Chosŏn Wangjo Sillok

[Veritable Records of the Kings of the Chosŏn Dynasty]. 48 vols. Seoul: Kuksa P’yŏnch'an Wiwŏnhoe.

Sŏnjo Sillok [Veritable Records of King Sŏnjo]. n.d. In Chosŏn Wangjo Sillok [Veritable Records of the Kings of the Chosŏn Dynasty]. 48 vols. Seoul: Kuksa P’yŏnch'an Wiwŏnhoe.

Sukchong Sillok [Veritable Records of King Sukchong]. n.d. In Chosŏn Wangjo Sillok [Veritable Records of the Kings of the Chosŏn Dynasty]. 48 vols. Seoul: Kuksa P’yŏnch'an Wiwŏnhoe.

Tanjong Sillok [Veritable Records of King Tanjong]. n.d. In Chosŏn Wangjo Sillok [Veritable Records of the Kings of the Chosŏn Dynasty]. 48 vols. Seoul: Kuksa P'yŏnch'an Wiwŏnhoe.

YI SAEk. n.d. "Ch'odong” [Woodcutting Youth]. In Mogŭn'go [Collected Works of Mokŭn], sigo vol. 22. Seoul: Han'guk Kojŏn Pŏnyŏgwŏn.

YI Sunsin. 2010. Nanjung Ilgi [War Diary of Yi Sunsin]. Translated into Korean and edited by No Sŭngsŏk. Seoul: Minŭmsa.

Yu HŭICH’un. 1992-96. Miam Ilgi [Diary of Miam]. 5 vols. Tamyang-gun, South Korea: Tamyang Hyangt'o Munhwa Yŏn'guwŏn.

Yun Sŏndo. 1655. “Sip’ye Sajo So” [Four Comments on the Ills of Our Time]. In Kosan Yugo [The Collected Works of Kosan]. Vol. 2. Seoul: Han'guk Kojŏn Pŏnyŏgwŏn.

\section{Secondary Sources}

Andrade, Tonio, Hyeok Hweon Kang, and Kirsten Cooper. 2014. “A Korean Military Revolution? Parallel Military Innovations in East Asia and Europe." Journal of World History 25(1):51-84.

Appunn, Karl. 2009. A Forest on the Sea: Environmental Expertise in Renaissance Venice. Baltimore: Johns Hopkins University Press.

ChŎN Yŏngu. 2005. Sup kwa Munhwa [Forests and Culture]. Seoul: Puksŭhil.

Deuchler, Martina. 2015. Under the Ancestors' Eyes: Kinship, Status, and Locality in Premodern Korea. Cambridge, Mass.: Harvard University Asia Center.

Hasegawa, Masato. 2016. "War, Supply Lines, and Society in the Sino-Korean Borderland of the Late Sixteenth Century." Late Imperial China 37(1):109-52.

Henthorn, W. E. 1963. Korea: The Mongol Invasions. Leiden: E. J. Brill.

Kang, Нүеok Hweon. 2013. "Big Heads and Buddhist Demons: The Korean Musketry Revolution and the Northern Expeditions of 1654 and 1658." Journal of Chinese Military History 2(2):127-89.

KIM KYŏNGoK. 2004. Chosŏn Hugi Tosŏ Yŏn'gu [A Study of Islands in the Late Chosŏn Era]. Seoul: Hyean.

Kim Kyŏngsuk. 2012. Chosŏn ŭi Myoji Sosong [Gravesite Lawsuits in the Chosŏn Dynasty]. P’aju, South Korea: Munhak Tongne.

Kim Kyoung-Soo. 2010. The Geography of Korea. Seoul: National Geographic Information Institute, Ministry of Land, Transport and Maritime Affairs.

KIm SŏNgu. 2001. Chosŏn Chunggi Kukka wa Sajok [The State and Elites in the MidChosŏn Era]. Seoul: Yŏksa Pip’yŏngsa.

Kim, Sun Joo, and Jungwon Kim. 2014. Wrongful Deaths: Select Inquest Records from Nineteenth-Century Korea. Seattle: University of Washington Press. 
Kim-Haboush, JaHyun. 2016. The Great East Asian War and the Birth of the Korean Nation. New York: Columbia University Press.

Matteson, Kieko. 2015. Forests in Revolutionary France: Conservation, Community, and Conflict, 1669-1848. Cambridge: Cambridge University Press.

Nam Toyŏng. 1996. Han'guk Majŏngsa [A History of Korean Horse Policies]. Kwach’ŏn, South Korea: Han'guk Masahoe.

Pak Wŏn’gyu and Yi KwanghŭI. 2007. “Uri Nara Kŏnch’uk e Sayong Toen Mokchae Sujong ŭi Pyŏnch'ŏn" [Changes in Tree Species Used in Korean Architecture]. Kŏnch’uk Yǒksa Yŏn’gu 16(1):9-27.

PyŏN NAmju. 2012. "Chosŏn Sidae Kukyŏng T’oji wa Sugunjin” [State Land Management and Military Garrisons in the Chosŏn Era]. In Nohwa Upchi [Nohwa Gazetteer], ed. Nohwa Üpchi Palgan Wiwŏnhoe [Nohwa Gazetteer Compilation Committee], 10520. Nohwa, South Korea: Nohwa Ŭpchi Palgan Wiwŏnhoe.

Rogers, Michael C. 1982-83. "P'yŏnnyŏn T'ongnok: The Foundation Legend of the Koryŏ State." Journal of Korean Studies 4:3-72.

Sasaki, Randall J. 2015. The Origins of the Lost Fleet of the Mongol Empire. College Station: Texas A\&M University Press.

Song Kijung. 2011. "17-18 Segi Chŏnban Sugun Yǒkche ŭi Unyŏng kwa Pyŏnhwa Yangnam Sugun Pyŏnt’ong Chŏlmok ŭl Chungsim Ǔro" [The Management and Transformation of Naval Forces Mobilization in the Seventeenth and early Eighteenth Centuries]. Taedong Munhwa Yón'gu 76:7-52.

Song Yangsŏp. 2006. Chosŏn Hugi Tunjŏn Yŏn'gu [A Study of Garrison Farms in the Late Chosŏn Dynasty]. Seoul: Kyŏngin.

Swope, Kenneth. 2005. "Crouching Tigers, Secret Weapons: Military Technology Employed during the Sino-Japanese-Korean War, 1592-1598." Journal of Military History 69(1):11-41.

Totman, Conrad. 1998. The Green Archipelago: Forestry in Pre-Industrial Japan. Athens: Ohio University Press.

Vera, F. W. M. 2000. Grazing Ecology and Forest History. Wallingford, UK: CABI Publishing.

Warde, Paul. 2006. "Fear of Wood Shortage and the Reality of the Woodland in Europe, c.1450-1850." History Workshop Journal 62(1):28-57.

Whitney, Gordon G. 1994. From Coastal Wilderness to Fruited Plain: A History of Environmental Change in Temperate North America, 1500 to the Present. Cambridge: Cambridge University Press.

WING, John T. 2015. Roots of Empire: Forests and State Power in Early Modern Spain, c. 1500-1750. Leiden: Brill.

Yi Min'ung. 2015. "The Role of the Chosonn Navy and Major Naval Battles during the Imjin Waeran.” In The East Asian War: 1592-1598: International Relations, Violence, and Memory, ed. James B. Lewis, 120-40. London: Routledge. 